\title{
In Vitro Characterization of Lactic Acid Bacteria from Indonesian Kefir Grains as Probiotics with Cholesterol-Lowering Effect
}

\author{
Dandy Yusuf ${ }^{1}$, Lilis Nuraidaa ${ }^{1,2 *}$, Ratih Dewanti-Hariyadi ${ }^{1,2}$, and Dase Hunaefi ${ }^{1,2}$ \\ 'Department of Food Science and Technology, Faculty of Agricultural Technology, IPB University (Bogor \\ Agricultural University), Bogor, West Java, Indonesia \\ ${ }^{2}$ Southeast Asian Food and Agricultural Science and Technology (SEAFAST) Center, IPB University (Bogor \\ Agricultural University), Bogor, West Java, Indonesia
}

Indonesian kefir grains are potential sources of lactic acid bacteria (LAB) that may act as probiotics with specific functional properties. In this study we explored the potential of the probiotic and cholesterol-lowering effect of LAB isolated from Indonesian kefir grains obtained from Bogor, Bandung, Jakarta, and Yogyakarta. The results revealed that 10 isolates showed considerable survivability at low $\mathrm{pH}$ and bile salt with total cell reduction of $\sim 3 \log$ colony-forming units per milliliter after exposure to $\mathrm{pH} 2.5$ and $0.5 \%(\mathrm{w} / \mathrm{v})$ bile salt for 1 and $3 \mathrm{~h}$, respectively. All strains exhibited strong antimicrobial activities against pathogenic bacteria and were sensitive to a wide spectrum of antibiotics but exhibited weak bile salt hydrolase activity. Identification based on $16 \mathrm{~S}$ RNA suggested that nine isolates were Lactobacillus kefiri and one was Lactobacillus rhamnosus. The ability of the isolates to reduce cholesterol from the media varied, ranging from $22.08 \%$ to $68.75 \%$ with the highest reduction shown by L. kefiri JK17. The ability to remove cholesterol from the media decreased greatly in resting and dead cells, ranging from $14.58 \%$ to $22.08 \%$ in resting cells and from $7.89 \%$ to $18.17 \%$ in dead cells. It can be concluded that Indonesian kefir grains contain LAB potentially acting as probiotics capable of reducing cholesterol. The cholesterol-lowering effect especially occurs when the cells are metabolically active.

Keywords: Cholesterol, kefir grains, lactic acid bacteria, Lactobacillus, probiotics

Received: October 14, 2019 Accepted: January 21, 2020

First published online: January 23,2020

*Corresponding author Phone: $+62-81111858$ Fax: +62-251869535 E-mail: Inuraida@gmail.com

pISSN 1017-7825 elSSN 1738-8872

Copyright(C) 2020 by The Korean Society for Microbiology and Biotechnology

\section{Introduction}

Kefir grain is a starter culture for the production of kefir. The grain is densely populated by lactic acid bacteria (LAB) species, acetic acid bacteria, and yeast. Kefir is reported to have many health benefits, such as prevention of lactose intolerance [1], antimicrobial [2] and antioxidant [3] effects, reduction of cholesterol [4], and prevention of diabetes [5]. It is suspected that these benefits originate from the presence and activity of LAB, which can act as probiotics [6] and/or agents producing bioactive compounds [7].

The Food and Agriculture Organization (FAO)/World Health Organization (WHO) defines probiotics as "living microorganisms that if consumed in sufficient quantities are able to provide health benefits to their host." Some of the requirements for probiotic bacteria are that they be generally recognized as safe (GRAS), have a history of use in food, and are able to survive in the upper gastrointestinal tract, namely, exposure to gastric acid $\mathrm{pH}(\sim 2.5)$ and bile salt $(\sim 0.5 \%)$ for 1 to $3 \mathrm{~h}$. In addition, probiotics should be sensitive to antimicrobials or antibiotics [8].

The WHO (2015) estimated that 17.5 million deaths occur annually because of cardiovascular disease. Cardiovascular disease is a non-communicable disease that can be caused by high cholesterol content in blood serum [9]. Many probiotic strains of LAB have been reported to possess cholesterol-reducing activity [10, 11]. Lactobacillus kefiri DH5 is one of the LAB from kefir, which has demonstrated probiotic properties and is able to reduce cholesterol [12]. The cholesterol-reducing activity in probiotics is strain dependent. The mechanisms of cholesterol reduction by probiotics include adsorption or attachment of cholesterol on the cell surface [13], assimilation or incorporation of cholesterol into the cellular membrane [14], incorporation and conversion to coprostanol [15], hydrolysis of glycine- or taurine-conjugated bonds to amino acids and free bile salts [16], and enzymatic de-conjugation by bile salt hydrolase (BSH) [17]. Studies on cholesterol removal by probiotic bacteria revealed that probiotic bacteria removed cholesterol through several different mechanisms $[11,14,18,19]$.

Traditionally, dairy products and their derivatives are the main source of LAB; however, currently, LAB have been isolated from traditional fermented food, meat, plants, humans, insects, soil, and marine creatures, and many of them showed probiotic characteristics [20,21]. Lactobacillus and Bifidobacterium are the most widely 
used groups of probiotic bacteria in food [8]. In previous studies, we have succeeded in isolating 30 LAB from Indonesian kefir grains obtained from Bogor, Bandung, Jakarta, and Yogyakarta (report in the process of publication). It is suspected that among these $\mathrm{LAB}$ isolates there are $\mathrm{LAB}$ with probiotic properties of cholesterollowering effect. The objectives of this study were to evaluate the potential probiotic properties of LAB from Indonesian kefir grains, identify the isolates, and evaluate their cholesterol-lowering effect.

\section{Materials and Methods \\ LAB Isolates}

A total of $30 \mathrm{LAB}$ isolates, including both rods and spheres, were obtained from four Indonesian kefir grains obtained from Bogor, Bandung, Jakarta, and Yogyakarta.

\section{Growth in Media Containing Bile Salt}

This test was performed for the initial selection of isolates capable of surviving bile salt. The inoculum was prepared by growing $\mathrm{LAB}$ at $37^{\circ} \mathrm{C}$ for $24 \mathrm{~h}$, and then as much as $1 \%$ was inoculated into de Man, Rogosa and Sharpe (MRS) broth supplemented with $0.5 \%(\mathrm{w} / \mathrm{v})$ bile salt (Oxgall; USA) and incubated at $37^{\circ} \mathrm{C}$ for $6 \mathrm{~h}$. Absorbance at 0 and $6 \mathrm{~h}$ was measured using an ultraviolet-visible (UV-Vis) spectrophotometer $\left(\mathrm{A}_{600}\right.$; Shimadzu, Japan). An increase in absorbance indicates cell growth.

\section{Evaluation for Probiotic Properties}

Acid and bile salt tolerance. Acid and bile salt tolerance was evaluated on the basis of the strains' survival after incubation at $\mathrm{pH} 2.5$ and bile acid [10]. The inoculum was prepared by centrifugation $\left(10,000 \times \mathrm{g}, 5 \mathrm{~min}, 4^{\circ} \mathrm{C}\right)$ of $1 \mathrm{ml}$ LAB culture in MRSB for $24 \mathrm{~h}$. For acid tolerance assay, cell pellets were re-suspended in phosphate-buffered saline (PBS; Oxoid) acidified using $0.1 \mathrm{~N} \mathrm{HCl}$ to $\mathrm{pH} 2.5$. As for the bile salt tolerance assay, cell pellets were resuspended in PBS supplemented with $0.3 \%(\mathrm{w} / \mathrm{v})$ bile salt. Incubation was done at $37^{\circ} \mathrm{C}$ for $1 \mathrm{~h}$ for acid tolerance and $3 \mathrm{~h}$ for bile salt tolerance assays. Enumeration of LAB counts at $0 \mathrm{~h}$ and after incubation was carried out on MRS agar at $37^{\circ} \mathrm{C}$ for $48 \mathrm{~h}$. The difference in the number of colonies before and after incubation shows a decrease in the number of $L A B$ due to acid or bile salt.

Antimicrobial activity. The antimicrobial activity of the LAB isolates was tested using the well diffusion method [22] against Salmonella typhimurium, Escherichia coli, and Bacillus cereus in Mueller-Hinton agar (Difco, USA).

Antibiotic resistance. Antibiotic resistance was tested for ampicillin (AMP), chloramphenicol (CHL), tetracycline (TET), and streptomycin (STR) [23], under compliance with the European Food Safety Authority (EFSA) [24] technical guidelines.

\section{BSH Activity}

Qualitative BSH activity evaluation was done by observing a precipitation zone after incubation of spotted culture on MRSA supplemented with $0.5 \%(\mathrm{w} / \mathrm{v})$ sodium salt of taurodeoxycholic acid and $0.37 \mathrm{~g} / \mathrm{CaCl}_{2}[10]$.

\section{Identification of LAB Isolates Based on $16 \mathrm{~S}$ rRNA Gene Sequence}

DNA extraction. Cell suspension was prepared by growing the isolate in MRSB supplemented with $0.1 \%$ glycine and incubated at $37^{\circ} \mathrm{C}$ for $24 \mathrm{~h}$. DNA extraction was done according to the manufacturer's instruction using a DNA extraction kit (Promega, USA).

Amplification. Amplification of the $16 \mathrm{~S}$ rRNA gene was carried out by polymerase chain reaction (PCR) using forward primer 27F (5'-AGAGTTTGATCCTGGCTCAG-3') and reverse primer 1492R (5'-GGTTACCTTGTT ACGACTT-3') [25]. The PCR mixture consisted of $15 \mu$ l GoTaq Green Master Mix (Promega), $0.6 \mu$ l primers $(10 \mu \mathrm{mol}), 2 \mu \mathrm{l}$ template, and $11.8 \mu \mathrm{l}$ nuclease-free water. The final volume of the PCR mixture was $30 \mu \mathrm{l}$. The PCR (Takara Thermal Cycler Dice Gradient, Japan) condition was as follows: pre-denaturation at $95^{\circ} \mathrm{C}$ for $5 \mathrm{~min}$, denaturation at $95^{\circ} \mathrm{C}$ for $1 \mathrm{~min}$ in $35 \mathrm{cycles}$, attachment at $58^{\circ} \mathrm{C}$ for $2 \mathrm{~min}$, elongation at $72^{\circ} \mathrm{C}$ for $2 \mathrm{~min}$, and final extension at $72^{\circ} \mathrm{C}$ for $10 \mathrm{~min}$.

Identification. The PCR products were then run on agarose gel electrophoresis. As much as $4 \mu \mathrm{l}$ PCR products were mixed with loading dye $(1 \mu \mathrm{l})$ and then placed in $1 \%(\mathrm{w} / \mathrm{v})$ agarose well in Tris-acetate-EDTA buffer solution. Electrophoresis was carried out at a voltage of $90 \mathrm{~V}$ for $45 \mathrm{~min}$, stained with ethidium bromide dye, and visualized using Gel Documentation System (Atto Corp., Japan) under UV light. The PCR products were sent to $1^{\text {st }}$ Base Laboratories (Malaysia) for sequencing. The sequencing data were then analyzed on MEGA7 software version 7.0, and the homology was searched through the Basic Local Alignment Search Tool (BLAST) on the National Center for Biotechnology Information website. A phylogenetic tree based on $16 \mathrm{~S}$ rDNA genes was then constructed.

\section{Cholesterol-Lowering Effect of Growing, Resting, and Dead Cells}

For evaluation of growing cells [10], LAB were grown in MRSB containing $0.5 \%$ bile salt at $37^{\circ} \mathrm{C}$ for $24 \mathrm{~h}$. The cell pellet was separated by centrifugation $\left(10,000 \times g, 5 \mathrm{~min}, 4^{\circ} \mathrm{C}\right)$ and inoculated into MRSB $+0.5 \%$ bile salt $+100 \mathrm{ppm}$ cholesterol (PEG-600; Sigma, USA). The mixture was then incubated at $37^{\circ} \mathrm{C}$ for $24 \mathrm{~h}$. For evaluation of resting cells, the cell pellet was inoculated into PBS solution $(\mathrm{pH} 6.8)+0.5 \%$ bile salt $+100 \mathrm{ppm}$ cholesterol and then incubated at $37^{\circ} \mathrm{C}$ for $24 \mathrm{~h}$. For evaluation of dead cells, the cell suspension in PBS was heated at $121^{\circ} \mathrm{C}$ for $15 \mathrm{~min}$. The cell pellet was then separated by centrifugation and inoculated into MRSB $+0.5 \%$ bile salt $+100 \mathrm{ppm}$ cholesterol. The mixture was then incubated at $37^{\circ} \mathrm{C}$ for $24 \mathrm{~h}$. The effect of cell concentration $(10 \times$ and $100 \times$ diluted cell suspension) of resting and growing cells on cholesterol removal was evaluated on the isolate with the highest removal ability. 


\section{Analysis of Cholesterol Removal}

The amount of cholesterol remaining in the medium was determined by O-phthalaldehyde (OPA) method [26] after cell separation by centrifugation $\left(10,000 \times g, 5 \mathrm{~min}, 4^{\circ} \mathrm{C}\right)$ to obtain the supernatant. The determination of cholesterol from the cell-free supernatant was based on colorimetric method using OPA (Sigma) measured at $550 \mathrm{~nm}$. Cholesterol concentration was determined using a standard curve. The percentage of cholesterol assimilation was determined by this formula: [Initial cholesterol concentration in the medium (ppm) Concentration of cholesterol remaining in culture $(\mathrm{ppm})]$ / Initial cholesterol concentration in the medium $\times 100 \%$.

\section{Scanning Electron Microscopy (SEM) Analysis}

SEM analyses were done on two representative isolates, i.e., L. kefiri JK17 and L. kefiri YK4. The growing, resting, and dead cells were prepared according to the method in Section F. As a control, the isolates were inoculated into MRSB without cholesterol. After incubation was completed, the culture was centrifuged $\left(10,000 \times g, 5 \mathrm{~min}, 4^{\circ} \mathrm{C}\right)$ and then rinsed twice with PBS solution ( $\mathrm{pH} \mathrm{7.0;} \mathrm{Oxoid).} \mathrm{The} \mathrm{cholesterol} \mathrm{attached} \mathrm{to} \mathrm{the}$ cell wall was then observed using low-vacuum SEM (JSM-5310LV; Jeol Ltd., Japan).

\section{Results and Discussion}

Growth in Media Containing Bile Salt

The results showed that all $30 \mathrm{LAB}$ isolates can grow in MRSB containing $0.5 \%$ bile salt. The increase in the absorption values varies with an average increase in absorbance of $63.66 \%$. A total of 19 isolates whose increased absorbance values were above average were selected for further evaluation.

\section{Acid Tolerance}

The $19 \mathrm{LAB}$ isolates showed varying tolerance to $\mathrm{pH} 2.5$, which is in agreement with various studies showing that the ability of LAB to survive low acid is strain dependent [27-29]. The number of cell decrease ranged between 0.57 and $2.04 \log$ colony-forming units (CFU)/ml. The $\mathrm{pH}$ value of 2.5 correlated with human stomach acidity. Isolates BG8, BG9, BG13, BD4, JK1, JK6, JK17, JK19, YK4, and YK7 showed a considerable tolerance to low $\mathrm{pH}$ as shown by slight decreases in viable cells (Table 1). Isolate JK1 was the most acid tolerant, with a decrease of $0.57 \log$ $\mathrm{CFU} / \mathrm{ml}$. Low acidity damages the cytoplasmic membrane and destroys the intracellular components of the cell, but some strains have stronger cytoplasmic membrane permeability and ability to adapt to low acidity [30]. Ten isolates with slight decrease in viable cells were then selected for further evaluation.

\section{Bile Salt Tolerance}

The results suggested that the $10 \mathrm{LAB}$ isolates that were most resistant to low $\mathrm{pH}$ showed various tolerance to $0.3 \%$ bile salt. The number of cell decrease ranged between 0.69 and $1.59 \log$ CFU/ml (Table 1). JK17 was the most tolerant to bile acid with a cell decrease of $0.69 \log \mathrm{CFU} / \mathrm{ml}$. The ability to tolerate bile salt is assumed to be associated with proteins or enzymes produced by LAB, which influence cell membrane, cell homeostatic properties, or change in the structure of bile salt [31]. Several LAB strains have been reported to produce BSH enzyme that can hydrolyze conjugated bile salt into deconjugated bile salt and decrease the toxicity level to the cells [32]; however, the present isolates were not strong BSH producers.

$\mathrm{JK} 17$ was the most prospective isolate, with a total decrease of $1.69 \log \mathrm{CFU} / \mathrm{ml}$ after exposure to bile salt and low $\mathrm{pH}$ (2.5; Table 1). The number of probiotics that are able to survive low $\mathrm{pH}$ and bile acid will determine the effectiveness of the probiotic. The dosage of $10^{6}$ to $10^{9} \mathrm{CFU} / \mathrm{ml}$ viable organisms reaching the intestinal tract in humans is considered as the most effective [33]. When it is assumed that the probiotic organism in the product is $10^{9} \mathrm{CFU} / \mathrm{ml}$, the decrease up to $10^{3} \mathrm{CFU} / \mathrm{ml}$ would be tolerable. Therefore, the 10 isolates obtained in the present research were considered as potential probiotics as shown by the total decrease of viable cells after exposure to low $\mathrm{pH}$ and bile acid (Table 1).

Table 1. Acid and bile salt tolerance of LAB isolated from Indonesian kefir grains.

\begin{tabular}{lccc}
\hline Strains & $\begin{array}{c}\text { Decrease of viable cells } \\
\text { after 1 h at pH 2.5 }\end{array}$ & $\begin{array}{c}\text { Decrease of viable cells } \\
\text { after 3 h at 0.3\% bile salt }\end{array}$ & Total decrease of viable cells \\
\cline { 2 - 3 } & $1.53^{\mathrm{ab}}$ & $(\log$ CFU/ml $)$ & 2.65 \\
BG8 & $1.69^{\mathrm{ab}}$ & $1.12^{\mathrm{ab}}$ & 3.28 \\
BG13 & $2.04^{\mathrm{a}}$ & $1.59^{\mathrm{abc}}$ & 3.11 \\
BD2 & $1.27^{\mathrm{b}}$ & $1.07^{\mathrm{a}}$ & 2.56 \\
BD4 & $0.57^{\mathrm{ab}}$ & $1.29^{\mathrm{abc}}$ & 1.97 \\
JK1 & $1.91^{\mathrm{ab}}$ & $1.40^{\mathrm{ab}}$ & 3.07 \\
JK5 & $1.28^{\mathrm{ab}}$ & $1.16^{\mathrm{bc}}$ & 2.78 \\
JK6 & $1.00^{\mathrm{b}}$ & $1.50^{\mathrm{bc}}$ & 1.69 \\
JK17 & $1.30^{\mathrm{b}}$ & $0.69^{\mathrm{bc}}$ & 2.26 \\
YK4 & $1.09^{\mathrm{b}}$ & $0.96^{\mathrm{bc}}$ & 2.08 \\
YK7 & $0.99^{\mathrm{c}}$ & \\
\hline
\end{tabular}

Means in the same column with different superscript letters are significantly different $(p<0.05)$ by Duncan's multiple range test. 


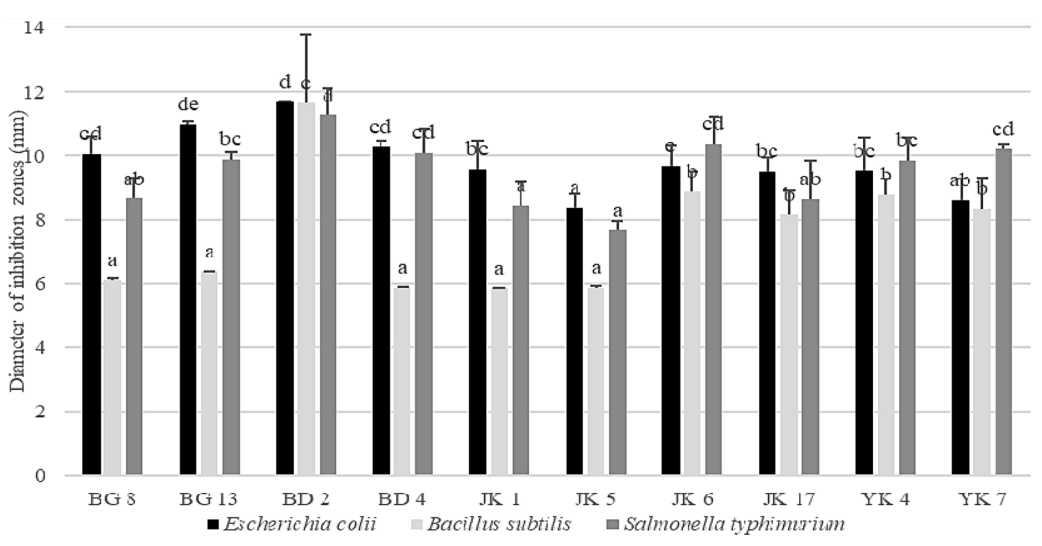

Fig. 1. Antimicrobial activity of LAB isolated from Indonesian kefir grains. Different superscript letters are significantly different $(p<0.05)$ by Duncan's multiple range test.

\section{Antimicrobial Activity}

The results of the experiment indicate that the $10 \mathrm{LAB}$ isolated from Indonesian kefir grains showed various antimicrobial activities (Fig. 1). Lactobacillus rhamnosus BD2 showed the greatest antimicrobial activity. Antimicrobial substances produced by LAB have been widely reported, including lactic acid, bacteriocin, reuterine, and reutericycline [21]. Lactic acid is the main product of LAB, so it is thought to be the major inhibitor. Although the isolates capable of producing bacteriocin, reuterine, or reutericycline are still unknown, it is necessary to carry out further research on the identification of antimicrobial substances produced by the isolates.

\section{Antibiotic Resistance}

The 10 isolates were sensitive to AMP, CHL, TET, and STR. The minimum inhibitory concentrations of antibiotics that inhibited the isolates were below the limit concentration set by EFSA for L. rhamnosus and L. kefiri. Antibiotic resistance is one of the safety indicators recommended by the FAO/WHO to be tested on probiotic candidates. This is due to the potential of probiotics to transfer antibiotic-resistant genes to other bacteria in the digestive system [34]. The antibiotics tested in this study are wide-spectrum commercial antibiotics, which inhibit gram-positive and gram-negative microbes [24].

\section{BSH Activity}

The 10 isolates tested in this study showed weak BSH activity as indicated by the thin precipitation zone compared with controls. The benefit of BSH production by probiotic bacteria is still under discussion. BSH produced by probiotics can help reduce host cholesterol [35], but some other researchers suggested that the activity of BSH probiotics is not entirely beneficial, because it is suspected that conjugated bile salts can be toxic compounds for the host, which can interfere with intestinal microbiota and cause digestive disorders [31].

\section{Identification of $16 \mathrm{~S}$ rRNA Gene Sequencing}

The PCR results of $16 \mathrm{~S}$ rRNA of the isolates on agarose gel electrophoresis are shown in Fig. 2. The amplicon size was $1,450 \mathrm{bp}$. The results of BLAST suggested that nine isolates had similarities of more than $99 \%$ with $L$. kefiri and one isolate had $99.79 \%$ similarity with L. rhamnosus. A similarity of more than $94 \%$ suggested high homology, and the samples were of the same species [36].

The phylogenetic tree of the 10 isolates formed two branches, namely, L. kefiri and L. rhamnosus with Lactobacillus plantarum as the outgroup (Fig. 3). The bootstrap value in two branches showed the percentage of the accuracy of the branching, which was statistically calculated to be as many as 1000 repetitions [37]. The bootstrap value showed that the divergences or separation by these branches were correct or reliable [38].
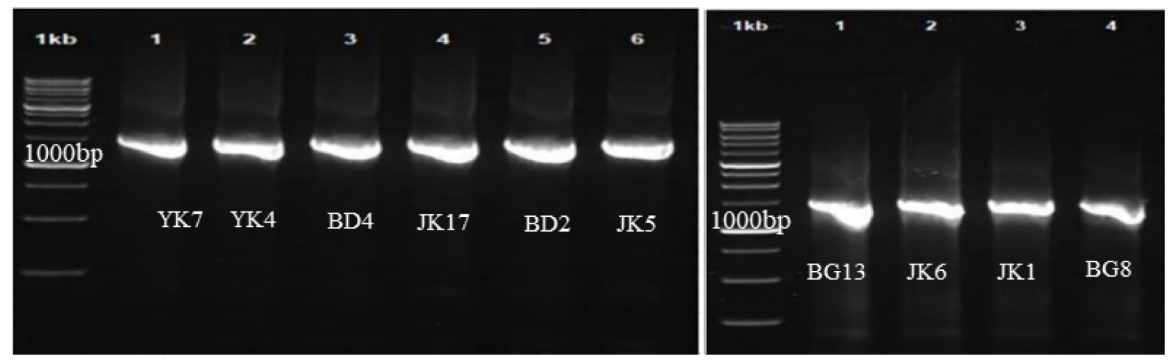

Fig. 2. PCR results of $16 S$ rRNA gene on agarose gel of $10 \mathrm{LAB}$ isolated from kefir grains. 


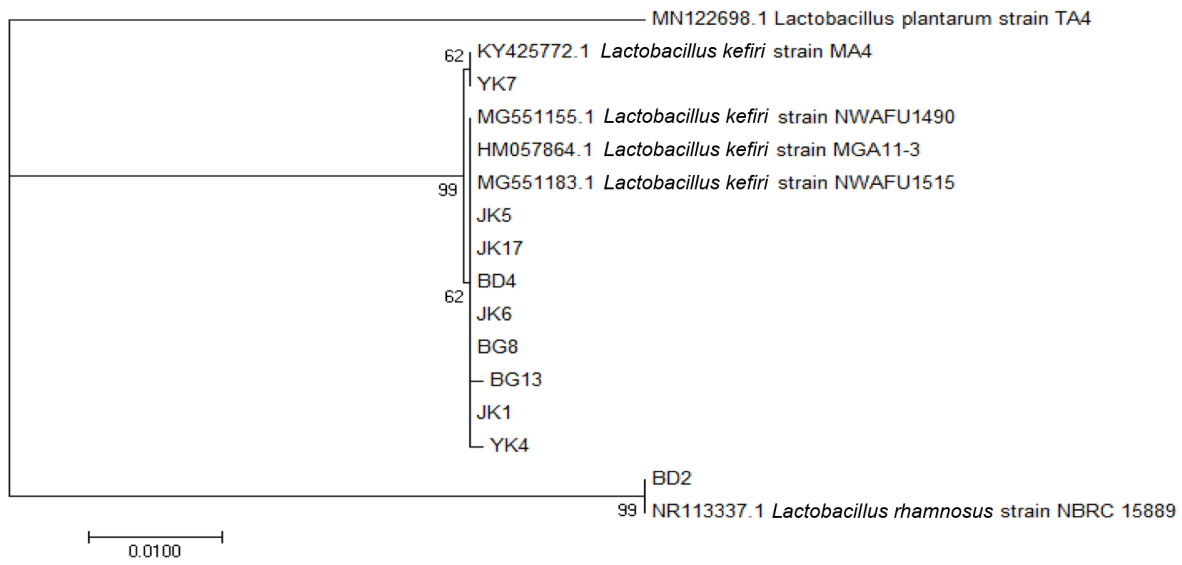

Fig. 3. Phylogenetic tree based on the homology of $16 \mathrm{~S}$ rRNA gene sequence of $10 \mathrm{LAB}$ isolated from Indonesian kefir grains.

\section{Cholesterol Removal by Growing, Resting, and Dead Cells}

Growing, resting, and dead cells of the $10 \mathrm{LAB}$ isolates were able to remove cholesterol from the medium (Table 2). Compared with resting and dead cells, growing cells reduced cholesterol the most. The greatest cholesterol reduction was observed in L. kefiri JK17 (i.e., 68.75\%). The value showed a significant difference $(p<0.05)$ compared with other strains, including L. rhamnosus $\mathrm{R} 23$ positive control [39]. Although the ability in removing cholesterol from the media decreased greatly in resting and dead cells, the reduction of cholesterol by resting cells was still higher than that by dead cells.

The results of this study confirm that cholesterol removal activity is strain dependent as shown by various degrees of reduction among L. kefiri. LAB cells in the growth phase have the greatest cholesterol removal effect. Similar results were also reported by other researchers on Lactobacillus isolated from fermented food [14], LAB from fermented mustard [18], and Lactococcus lactis subsp. lactis [19]. Growing cells were suggested to have the ability to assimilate and absorb cholesterol as fatty acid for constructing cell membranes [40] and converting cholesterol to coprostanol [15]. Cholesterol uptake by growing cells causes the difference in levels of cholesterol removal from the medium [18]. For in vitro study, the most suggested mechanism of cholesterol removal is assimilation or incorporation of cholesterol into cells and adhesion of cholesterol on the cell surface [14]; however, the present study showed only a small degree of cholesterol removal by resting and dead cells, suggesting that the main mechanism was uptake by growing cells. The present results suggested that high cholesterol removal is growth associated and might depend on the metabolic process. When growth ceases, the ability to remove cholesterol significantly decreases. Our results were different from previous report [10] that growing, resting, and dead cells of $L$. plantarum EM showed high cholesterol removal.

The present results also showed that when resting cells were diluted by $10 \times$ (about $8 \log \mathrm{CFU} / \mathrm{ml}$ ), the cholesterol removed was significantly lower as compared to undiluted cells $\left(10^{9} \mathrm{CFU} / \mathrm{ml}\right.$; Table 3$)$. However, cholesterol removed by $100 \times$ dilution of resting cells was not significantly different from that by $10 \times$ dilution. There was no significant difference on the effect of biomass concentration on the cholesterol removed by the dead cells. The results support that the mechanism of cholesterol removal from the media by the isolates may involve metabolism and not depend on cell surface attachment.

Table 2. Cholesterol removal from the medium by LAB isolated from Indonesian kefir grains.

\begin{tabular}{|c|c|c|c|}
\hline \multirow{2}{*}{ LAB isolates } & \multicolumn{3}{|c|}{ Cholesterol reduced from the medium after $24 \mathrm{~h}(\%)$} \\
\hline & Growing cells & Resting cells & Dead cells \\
\hline L. kefiri BG8 & $22.08^{\mathrm{eEF}}$ & $16.67^{\mathrm{aEF}}$ & $15.11^{\mathrm{aEF}}$ \\
\hline L. kefiri BG13 & $28.33^{\mathrm{deDE}}$ & $17.92^{\mathrm{aF}}$ & $12.33^{\mathrm{aEF}}$ \\
\hline L. rhamnosus BD2 & $53.75^{\mathrm{bB}}$ & $20.42^{\mathrm{aEF}}$ & $16.69^{\mathrm{aEF}}$ \\
\hline L. kefiri BD4 & $36.25^{\mathrm{cdCD}}$ & $16.25^{\mathrm{aF}}$ & $10.33^{\mathrm{aEF}}$ \\
\hline L. kefiri JK1 & $42.50^{\mathrm{bcBC}}$ & $14.58^{\mathrm{aF}}$ & $7.89^{\mathrm{aEF}}$ \\
\hline L. kefiri JK5 & $42.50^{\mathrm{bcBC}}$ & $16.67^{\mathrm{aEF}}$ & $12.75^{\mathrm{aEF}}$ \\
\hline L. kefiri JK6 & $37.50^{\mathrm{cdCD}}$ & $18.33^{\mathrm{aEF}}$ & $14.83^{\mathrm{aEF}}$ \\
\hline L. kefiri JK17 & $68.75^{\mathrm{aA}}$ & $22.08^{\mathrm{aEF}}$ & $15.81^{\mathrm{aEF}}$ \\
\hline L. kefiri $\mathrm{YK} 4$ & $46.67^{\mathrm{bcBC}}$ & $21.67^{\mathrm{aEF}}$ & $18.17^{\mathrm{aEF}}$ \\
\hline L. kefiri YK7 & $36.25^{\mathrm{cdCD}}$ & $17.92^{\mathrm{aEF}}$ & $12.06^{\mathrm{aEF}}$ \\
\hline L. rhamnosus $\mathrm{R} 23$ & $20.83^{\mathrm{eEF}}$ & $14.17^{\mathrm{aF}}$ & $10.25^{\mathrm{aEF}}$ \\
\hline
\end{tabular}

Means with different superscript letters in the same column $(\mathrm{a}-\mathrm{d})$ and superscript capital letters in the same row (A-F) are significantly different $(p<0.05)$ by Duncan's multiple range test. 
Table 3. Cholesterol removal by different cell concentrations of resting and dead cells of $L$. kefiri JK17.

\begin{tabular}{lccc}
\hline \multirow{2}{*}{ Cell conditions } & \multicolumn{3}{c}{ Cholesterol reduced from the medium $(\%)$} \\
\cline { 2 - 4 } & $9 \mathrm{CFU} / \mathrm{ml}^{*}$ & $8 \mathrm{CFU} / \mathrm{ml}$ & $7 \mathrm{CFU} / \mathrm{ml}$ \\
\hline Resting cells & $22.08^{\mathrm{a}}$ & $13.75^{\mathrm{b}}$ & $10.00^{\mathrm{bc}}$ \\
Dead cells & $15.81^{\mathrm{a}}$ & $15.00^{\mathrm{ab}}$ & $11.25^{\mathrm{b}}$ \\
\hline
\end{tabular}

${ }^{\star}$ The viable cell concentration before incubation as resting cells and before heat killing was $1.26 \times 10^{9} \mathrm{CFU} / \mathrm{ml}$. Means in the same row with different superscript letters are significantly different $(p<0.05)$ by Duncan's multiple range test.

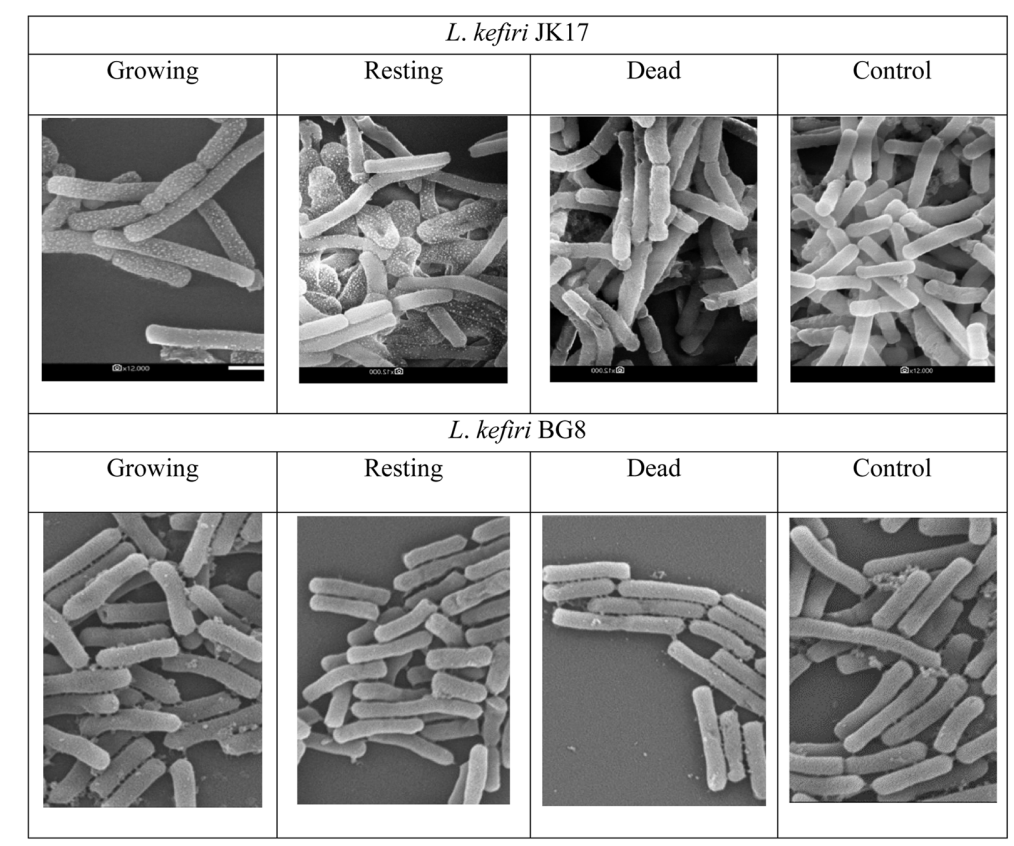

Fig. 4. SEM images of L. kefiri JK17 and L. kefiri BG8 after incubation in media containing cholesterol (magnification of $12,000 \times$ ).

\section{SEM Analysis}

SEM observation showed that cholesterol also attached to the cell surface (Fig. 4). The most attachment of cholesterol was shown on growing cells of L. kefiri JK17 compared with resting and dead cells. A small degree of cholesterol attached to the resting cells of $L$. kefiri JK17; however, almost no cholesterol was attached to the cell surface of dead cells, many of which appeared to be damaged. L. kefiri BG8 reduced cholesterol the least (Table 2). SEM observation showed that only a limited amount of cholesterol attached on the cell surface of L. kefiri BG8 (Fig. 4) and almost no cholesterol attached to resting and dead cells of L. kefiri BG8. SEM evaluation supported that cholesterol removal by LAB isolated from Indonesian kefir grain depends on the metabolic process of the live cells. Attachment on the cell surface was not the main the mechanism of cholesterol removal in the present study. Removal of cholesterol through several mechanisms has also been reported by other researchers $[11,14,18,19]$.

The present study revealed that nine L. kefiri strains and one L. rhamnosus strain isolated from Indonesian kefir grains meet the prerequisite criteria to be candidate probiotic bacteria, such as acid and bile tolerance, antimicrobial activity, and sensitivity to antibiotics. The 10 strains also showed cholesterol-lowering effect in growing or metabolic active state but much lower in resting and dead cells. L. kefiri JK17 is considered as the probiotic candidate having the best potential with the the specific function of cholesterol-lowering effect, especially in growing state. Removal of cholesterol by the isolate is expected to reduce cholesterol availability for absorption from the intestine into the blood. Therefore, further in vivo studies are required to confirm the isolate's probiotic and cholesterol-lowering effect. The elucidation of the mechanism of how L. kefiri JK17 removes cholesterol is also an area that needs to be pursued.

\section{Acknowledgments}

This research was supported by a competition-based research program in the Indonesian Ministry of Research and Higher Education (RISTEKDIKTI) in 2018 to 2019 for the recipient Lilis Nuraida.

\section{Conflict of Interest}

The authors have no financial conflicts of interest to declare. 


\section{References}

1. Hertzler SR, Clancy SM. 2003. Kefir improves lactose digestion and tolerance in adults with lactose maldigestion. J. Am. Diet. Assoc. 103: $582-587$

2. Kim DH, Jeong D, Kim H, Kang IB, Chon JW, Song KY, et al. 2016. Antimicrobial activity of kefir against various food pathogens and spoilage bacteria. Korean J. Food Sci. Anim. Resour. 36: 787-790.

3. Ozcan A, Kaya N, Atakisi O, Karapehlivan M, Atakisi E, Cenesiz S. 2009. Effect of kefir on the oxidative stress due to lead in rats. J. Appl. Anim. Res. 35: 91-93.

4. Liu JR, Wang SY, Chen MJ, Chen HL, Yueh PY, Lin CW. 2006. Hypocholesterolaemic effects of milk kefir and soyamilk kefir in cholesterol-fed hamsters. Br. J. Nutr. 95: 939-946.

5. Hadisaputro S, Djokomoeljanto RRJ, Judiono, Soesatyo MHNE. 2012. The effects of oral plain kefir supplementation on proinflammatory cytokine properties of the hyperglycemia Wistar rats induced by streptozotocin. Acta Med. Indones. 44: 100-104.

6. Halloran K, Underwood MA. 2019. Probiotic mechanisms of action. Early Hum. Dev. 135: 58-65.

7. Chaves-López C, Serio A, Paparella A, Martuscelli M, Corsetti A, Tofalo R, et al. 2014. Impact of microbial cultures on proteolysis and release of bioactive peptides in fermented milk. Food Microbiol. 42: 117-121.

8. FAO/WHO. 2002. Working group report on drafting guidelines for the evaluation of probiotics in food. World Health Organization and Food and Agriculture Organization of the United Nations. Ontario: London.

9. Bhatnagar D, Soran H, Durrington PN. 2008. Hypercholesterolaemia and its management. BMC 337: a993.

10. Choi EA, Chang HC. 2015. Cholesterol-lowering effects of a putative probiotic strain Lactobacillus plantarum EM isolated from kimchi. LWT - Food Sci. Technol. 62: 210-217.

11. Tomaro-Duchesneau C, Jones ML, Shah D, Jain P, Saha S, Prakash S. 2014. Cholesterol assimilation by lactobacillus probiotic bacteria: an in vitro investigation. Biomed. Res. Int. 2014.

12. Kim DH, Jeong D, Kang IB, Kim H, Song KY, Seo KH. 2017. Dual function of Lactobacillus kefiri DH5 in preventing high-fat-dietinduced obesity: direct reduction of cholesterol and upregulation of PPAR- $\alpha$ in adipose tissue. Mol. Nutr. Food Res. 61: 1-35.

13. Miremadi F, Ayyash M, Sherkat F, Stojanovska L. 2014. Cholesterol reduction mechanisms and fatty acid composition of cellular membranes of probiotic Lactobacilli and Bifidobacteria. J. Funct. Foods 9: 295-305.

14. Anila K, Kunzez A, Bhalla TC. 2016. In vitro cholesterol assimilation and functional enzymatic activities of putative probiotic Lactobacillus sp. isolated from fermented foods/ beverages of north west India. J. Nutr. Food Sci. 6: 2.

15. Lye HS, Rusul G, Liong MT. 2010. Removal of cholesterol by Lactobacilli via incorporation and conversion to coprostanol. J. Dairy Sci. 93: 1383-1392.

16. Gilliland SE, Nelson CR, Maxwell C. 1985. Assimilation of cholesterol by Lactobacillus acidophilus. Appl. Environ. Microbiol. 49: 377381 .

17. Guo CF, Zhang LW, Han X, Li JY, Du M, Yi HX, et al. 2011. Short communication: A sensitive method for qualitative screening of bile salt hydrolase-active lactobacilli based on thin-layer chromatography. J. Dairy Sci. 94: 1732-1737.

18. Wang SC, Chang CK, Chan SC, Shieh JS, Chiu CK, Duh PD. 2014. Effects of lactic acid bacteria isolated from fermented mustard on lowering cholesterol. Asian Pac. J. Trop. Biomed. 4: 523-528.

19. Shehata MG, El Sohaimy SA, El-Sahn MA, Youssef MM. 2016. Screening of isolated potential probiotic lactic acid bacteria for cholesterol lowering property and bile salt hydrolase activity. Ann. Agric. Sci. 61: 65-75.

20. Nuraida L. 2015. A review?: Health promoting lactic acid bacteria in traditional Indonesian fermented foods. Food Sci. Hum. Wellness. 4: 47-55.

21. Teneva-angelova T, Hristova I, Pavlov A. 2018. Lactic acid bacteria - from nature through food to health, pp. 91-133. In the Handbook of Food Bioengineering, Advances in Biotechnology for Food Industry, 14th Ed. Academic Press. Elsevier.

22. Liasi SA, Azmi TI, Hassan MD, Shuhaimi M, Rosfarizan M, Ariff AB. 2009. Antimicrobial activity and antibiotic sensitivity of three isolates of lactic acid bacteria from fermented fish product, Budu. Malays. J. Microbiol. 5: 33-37.

23. Ryu EH, Chang HC. 2013. In vitro study of potentially probiotic lactic acid bacteria strains isolated from kimchi. Ann. Microbiol. 63: 1387-1395.

24. EFSA. 2010. Guidance on the risk assessment of genetically modified microorganisms and their food and feed products. EFSA J. 1-67.

25. Zanirati DF, Abatemarco M, Sandes SH de C, Nicoli JR, Nunes ÁC, Neumann E. 2015. Selection of lactic acid bacteria from Brazilian kefir grains for potential use as starter or probiotic cultures. Anaerobe 32: 70-76.

26. Rudel LL, Morris MD. 1973. Determination of cholesterol using o-phthalaldehyde. J. Lipid Res. 14: 364-6.

27. Cotter PD, Hill C. 2003. Surviving the acid test: Responses of Gram-Positive bacteria to low pH. Microbiol. Mol. Biol. Rev. 67: 429-453.

28. Tokatl M, Gulgor G, Elmac SB, Isleyen NA, Ozcelik F. 2015. In Vitro properties of potential probiotic indigenous lactic acid bacteria originating from traditional pickles. Biomed. Res. Int. 2015: 1-8.

29. Jacobsen CN, Nielsen VR, Hayford AE, Møller PL, Michaelsen KF, Pærregaard A, Sandström B, Tvede M, Jakobsen M. 1999. Screening of probiotic activities of forty-seven strains of Lactobacillus spp. by in vitro techniques and evaluation of the colonization ability of five selected strains in humans. Appl. Environ. Microbiol. 65: 4949-4956.

30. Kimoto H, Kurisaki J, Tsuji NM, Ohmomo S, Okamoto T. 1999. Lactococci as probiotic strains: Adhesion to human enterocyte-like Caco-2 cells and tolerance to low $\mathrm{pH}$ and bile. Lett. Appl. Microbiol. 29: 313-316.

31. Begley M, Gahan CGM, Hill C. 2005. The interaction between bacteria and bile. FEMS Microbiol. Rev. 29: 625-651.

32. De Smet I, Van Hoorde L, Vande Woestyne M, Christiaens H, Verstraete W. 1995. Significance of bile salt hydrolytic activities of lactobacilli. J. Appl. Bacteriol. 79: 292-301.

33. Sarkar S, Sur A, Sarkar K, Majhi R, Basu S, Chatterjee K, Sikder B. 2016. Probiotics: A way of value addition in functional food. Int. J. Food Sci. Nutr. Diet. 5: 290-293.

34. Broaders E, Gahan CGM, Marchesi JR. 2013. Potential for spread of antibiotic resistance genes mobile genetic elements of the human gastrointestinal tract. Gut Microbes. 4: 271-280.

35. Guo L, Wang L, Liu F, Li B, Tang Y, Yu S, Zhang D. 2019. Effect of bile salt hydrolase-active Lactobacillus plantarum KLDS 1.0344 on cholesterol metabolism in rats fed a high-cholesterol diet. J. Funct. Foods 61:103497.

36. Clarridge JE. 2004. Impact of $16 \mathrm{~S}$ rRNA gene sequence analysis for identification of bacteria on clinical microbiology and infectious diseases. Clin. Microbiol. Rev. 17: 840-862.

37. Horiike T, Miyata D, Hamada K, Saruhashi S, Shinozawa T, Kumar S, Chakraborty R, Komiyama T, Tateno Y. 2009. Phylogenetic construction of 17 bacterial phyla by new method and carefully selected orthologs. Gene 429: 59-64.

38. Tamura K, Dudley J, Nei M, Kumar S. 2007. MEGA4: Molecular evolutionary genetics analysis (MEGA) software version 4.0. Mol. Biol. Evol. 24: 1596-1599.

39. Maryati Y, Nuraida L, Dewanti-Hariyadi R. 2016. A study in vitro of latic acid bacteria (LAB) isolates on cholesterol lowering ability in the presence of oligosaccharides. Agritech. 36: 196-205.

40. Kimoto H, Ohmomo S, Okamoto T. 2002. Cholesterol removal from media by Lactococci. J. Dairy Sci. 85: 3182-3188. 